Vol. 11 no 1 junho 2009

\title{
O DISCURSO PEDAGÓGICO DE UM PROFESSOR E A ELABORAÇÃO DE CONHECIMENTOS CIENTÍFICOS
}

\section{THE TEACHER'S PEDAGOGICAL DISCOURSE AND THE CONCEPTUAL SCIENTIFIC PROCESS}

\author{
Lenice Heloísa de Arruda Silva * \\ Roseli Pacheco Schnetzler ${ }^{* *}$
}

\begin{abstract}
Resumo
O trabalho enfoca o discurso de um formador (professor universitário) visando a elaboração de conceitos científicos em seus alunos (futuros professores de Biologia), no contexto de uma disciplina de conteúdo específico (Fisiologia). Para tal, foram observadas, registradas e transcritas aulas teóricas e práticas do formador, gravadas em áudio. Os dados da investigação são construídos e interpretados segundo procedimentos teórico-metodológicos de uma perspectiva histórico-cultural e enunciativa, adotando-se a análise microgenética para investigar o discurso pedagógico do formador. Os resultados revelam aspectos que caracterizam a complexidade das interações professor-aluno em sala de aula, evidenciando estratégias discursivas, por parte do formador, que na visão daquele formador asseguram a transmissão de conhecimentos e a consideração das idéias dos alunos.
\end{abstract}

Palavras-chave: interações discursivas; elaboração conceitual; formação docente inicial

\begin{abstract}
This research focuses how a lecturer has promoted the process of constructing scientific concepts by his students, future biological teachers, through the analysis of his discourse. In this sense, five of his theoretical and practical lessons were observed, audio recorded and transcribed. By means of a microgenetic analysis, theoretical contributions of a historical, cultural and enunciative approach data were constructed and interpreted. Results reveal some aspects that have characterized the complexity of teacher-student interactions and some discourse strategies used by the lecturer in order to assure his knowledge transmission, as well his consideration for the students' ideas and doubts.
\end{abstract}

Keywords: teacher-student interactions; conceptual process; initial teacher education

\section{INTRODUÇÃO}

\footnotetext{
* UFGD/Faculdade de Ciências Biológicas e Ambientais, Professora Adjunta; UFMS, Professora do Curso de Mestrado em Ensino de Ciências.

** UNIMEP, Professora do Programa de Pós-Graduação em Educação.
} 


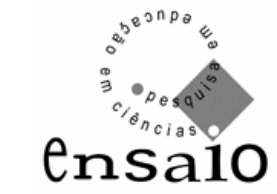

Vol. 11 no 1 junho 2009

A presente investigação se fundamenta em uma perspectiva histórico-cultural do desenvolvimento humano, a partir das idéias de Vygotsky e da perspectiva enunciativa de Bakhtin, que concebem o processo de elaboração de conhecimentos como processo psicológico que emerge dos modos de vida dos indivíduos em interação, assumindo que é por meio da linguagem que as funções psicológicas vão se constituindo. Nessa concepção, o conhecimento tem sua gênese na dinâmica interativa das relações sociais, as quais são constitutivas do indivíduo humano como sujeito. Em outros termos, o conhecimento é socialmente constituído, sendo a relação sujeitoobjeto de conhecimento sempre mediada pelo outro, pelas práticas sociais e pela linguagem (SMOLKA, 1997; GÓES, 1997).

De acordo com essas idéias, a educação como uma prática social, no contexto de escolarização, incluindo o universitário, o aluno é um sujeito interativo, que “elabora conhecimentos sobre os objetos em processos necessariamente mediados pelo outro e constituídos pela linguagem” (GÓES, 1997, p. 13) [grifo da autora]. Nesse contexto, o papel mediador do (outro) professor se destaca não somente nos processos de apropriação e elaboração de conhecimentos pelo aluno mas, também, na sua constituição como sujeito/profissional.

De acordo com Vygotsky (2000a), o processo de desenvolvimento dos conceitos sistematizados/científicos se produz nas condições reais do processo de ensino, que constitui uma forma de interação sistemática e deliberada do professor com o aluno. Nesta interação desenvolvem-se as funções psicológicas superiores do aluno com a ajuda e participação do professor. Esse desenvolvimento encontra sua expressão na crescente utilização dos conceitos independentemente do contexto no qual foram produzidos e, também, no fato de que o pensamento científico do aluno avança até alcançar um determinado nível de desenvolvimento em relação à tomada de consciência e ao uso deliberado dos mesmos. Neste sentido, a apropriação de conceitos científicos por parte do indivíduo pode levá-lo a se conscientizar dos próprios processos mentais.

Para Vygotsky (2000b) esse nível de desenvolvimento é produto/produção das condições do processo de ensino, cujo aspecto fundamental é a singular interação 


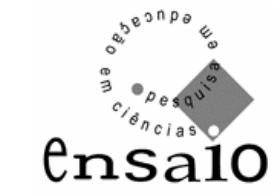

Vol. 11 no 1 junho 2009

entre professor e aluno. Essa interação junto com os conhecimentos que são transmitidos ao aluno segundo um determinado sistema. Nesses termos, no contexto escolar, as interações entre os sujeitos têm uma orientação explícita e deliberada, no sentido de aquisição de conceitos sistematizados/científicos pelo aluno. Nessas interações, o aluno é colocado diante de uma tarefa particular: "entender as bases dos estudos científicos, ou seja, um sistema de concepções científicas” (VYGOTSKY, 2000b, p. 174). Os conceitos científicos fazem parte de sistemas explicativos globais, organizados dentro de uma lógica socialmente construída e reconhecida como legítima, que tem por finalidade garantir-lhes coerência interna. Também, nesse contexto, a relação do aluno com o conceito é sempre mediada por algum outro conceito.

Além disso, no contexto escolar, as interações entre os sujeitos, isto é, entre professor e alunos, se caracteriza como uma relação de ensino, cuja finalidade imediata - ensinar/aprender ou formar/ser formado - é explicita para ambos, os quais ocupam lugares sociais diferenciados e hierarquicamente organizados (FONTANA, 1996).

Nesse contexto, com relação à linguagem, especialmente a palavra como signo, ela é o principal agente de abstração e generalização, assumindo um papel central como mediadora na formação da consciência e na organização das ações, assim como na compreensão e na interpretação de conceitos/conhecimentos por parte dos sujeitos (VYGOTSKY, 2000a; BAKHTIN, 1997).

Essa concepção da linguagem, na abordagem dos aspectos institucionais, tem uma dimensão constitutiva, pois à palavra é atribuído “o material semiótico privilegiado do psiquismo humano” (BAKHTIN, 1997, p. 38). Aqui há um entendimento de que é no discurso e pelo discurso que os conhecimentos são elaborados. Explicitando essa idéia, Smolka (2003, p. 40), expressa que: “é no sentido da internalização do discurso de outrem que Bakhtin nos fala (...) do movimento de apreensão das “palavras alheias” e na transformação dessas "palavras alheias” em palavras próprias”. Desse modo, o processo de elaboração de conhecimentos, concebido à luz do "princípio dialógico de Bakhtin”, “emerge como processo de articulação, pelo confronto, de múltiplas vozes historicamente definidas, em condições 


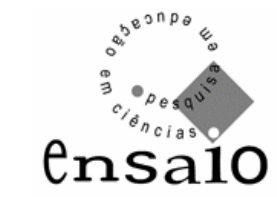

Vol. 11 no 1 junho 2009

de interação - compreensão/expressão - determinadas. Configura-se como um processo discursivo” (FONTANA, 1996, p. 280).

Bakhtin (1997) considera que o sujeito se constitui na dinâmica interativa das relações sociais, concebendo que não há atividade mental desligada das condições concretas de produção das interlocuções, que são determinadas pelo contexto social imediato e mais amplo dos interlocutores. A partir disso, em seus estudos, ele propõe que se analise a dinâmica interativa das relações no contexto social imediato e nas condições concretas de produção das enunciações, que são sempre parte de um “diálogo social ininterrupto". Os interlocutores têm sempre um horizonte social e uma audiência que configuram as trocas verbais de acordo com as diversas esferas da prática social. Desse modo, os lugares sociais que o sujeito ocupa nas relações com os outros marcam o para quê e o para quem de suas ações e de seus dizeres, delineando o que pode (ou não) dizer desses lugares, sugerindo modos de dizer. Essas condições, diz Fontana (2003, p. 62) com base no pensamento de Bakhtin, “explicitam as relações de poder implicadas nas relações sociais. Elas modulam o discurso e o próprio modo de apresentação do sujeito como tal, que vamos produzindo na dinâmica interativa”.

Assim, na perspectiva histórico-cultural do desenvolvimento humano, o processo de elaboração de conhecimentos é concebido como produção material e simbólica, que se constitui na dinâmica interativa das relações sociais, as quais envolvem a linguagem e o funcionamento interpessoal, significando que "é na interação com outro que o sujeito se constitui e que se dá a elaboração conceitual” (MACHADO, 1999, p. 50).

No dizer de Fontana (1996, p. 3), nessa perspectiva se “considera o processo de conceitualização como uma prática social dialógica (mediada pela palavra) e pedagógica (mediada pelo outro)”. [grifos da autora]. Esses aspectos são essenciais para a análise do processo de elaboração/compreensão de conceitos na sala de aula, em especial, da universidade, já que nesta a palavra é o principal modo de ação pedagógica do professor e de elaboração de conhecimentos. Com base nessas idéias, procuramos investigar como o discurso pedagógico de um professor universitário de disciplina de conteúdo específico (Fisiologia) promove a elaboração de conceitos científicos em futuros professores de Biologia? 


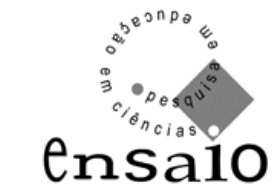

Vol. 11 no 1 junho 2009

\section{JUSTIFICATIVA}

A justificativa para desenvolver esta investigação se pauta nas críticas apontadas pela literatura de que usualmente nas disciplinas específicas, durante a formação inicial, os licenciandos de Ciências (Biologia, Física e Química) se habituam à recepção de conhecimentos de forma passiva, pois há uma elevada exposição de conteúdos pelos formadores (professores universitários), os quais detêm o discurso na aula, dificilmente interrompido por questões, dúvidas ou curiosidades dos licenciandos, que, por sua vez, limitam-se a copiar da lousa ou das transparências uma grande quantidade de fatos, conceitos, fórmulas e resoluções de "problemaspadrão” transmitidos, geralmente, com respostas únicas e verdadeiras (CARVALHO e GIL-PÉREZ, 1993).

Em face disso, nas referidas disciplinas, pouca ou nenhuma consideração tem sido dada para as questões pedagógicas necessárias às elaborações conceituais por parte dos alunos. Isto porque, usualmente, os formadores dessas disciplinas vêm interpretando e reforçando um processo de ensino-aprendizagem em termos de transmissão-recepção que atribui grande peso à quantidade de conteúdos científicos e não propicia aos alunos a elaboração de outros/novos conhecimentos, pois são considerados tabula rasa, que reproduzirão de forma integral em sua vida social/profissional os conteúdos transmitidos pelo professor (MARCELO, 1999; MALDANER, 2000; SCHNETZLER, 2000). Tal problemática pode propiciar que os futuros professores, quando no exercício da docência, neguem a validade de sua formação na graduação, exatamente naquilo que os cursos de licenciatura em Ciências mais prezam: dar uma boa base em conteúdos. Isso não significará que não saibam o conteúdo específico, mas que têm dificuldades de cunho pedagógico, o que pode comprometer a promoção da elaboração conceitual em seus alunos (MALDANER, 2000).

Assumindo a importância dos formadores das disciplinas específicas para os processos de apropriação/elaboração de conhecimentos pelo futuro professor no contexto da sua formação docente inicial - cursos de licenciatura - é que justificamos 


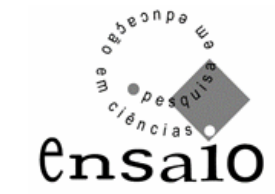

Vol. 11 no 1 junho 2009

a realização desta investigação, visando contribuir para a compreensão da problemática aqui enfocada.

\section{PROCEDIMENTOS METODOLÓGICOS}

O desenvolvimento deste trabalho implicou a investigação da prática pedagógica de um formador de disciplina específica integrante de um corpo docente de 17 professores universitários, responsáveis pelo oferecimento de 30 disciplinas de conteúdos específicos de Biologia, de um curso noturno de licenciatura em Ciências Biológicas, pertencente a uma universidade confessional localizada em um município do Estado de São Paulo.

O formador escolhido exerce o magistério superior há 12 anos. Sua formação básica é em Biologia (licenciatura plena), sendo mestre e doutor na área de Fisiologia. O interesse na investigação de sua prática pedagógica, com o propósito de evidenciar como o seu discurso pedagógico promove a elaboração de conceitos científicos pelos seus alunos, foi resultado de uma exploração inicial no curso de licenciatura especificado, ao entrevistar sete licenciandos que realizavam o estágio supervisionado, a fim de saber quais foram as principais contribuições e limitações do curso para suas futuras ações como professores de Ciências/Biologia.

Com relação às limitações, os licenciandos reiteraram o que Maldaner (2000) aponta sobre as principais críticas em relação aos cursos de formação de professores de Ciências, as quais vão desde a falta de didática da maioria dos professores da graduação, passando pela dicotomia das aulas práticas e teóricas, até a falta de transparência dos conteúdos para o ensino fundamental e médio. Quanto às contribuições, três licenciandos apontaram o referido formador devido à sua didática, ao domínio dos conteúdos científicos de sua disciplina e ao tipo de interação que estabelecia com os alunos na aula, culminando com o depoimento de uma licencianda:

Eu acho que ele é um professor pedagogicamente correto, porque ele fazia tudo que a gente sabe e lê sobre o que um professor precisa fazer para que o aluno aprenda o conteúdo. Ele sabia fazer as interações, fazer com que o aluno se interessasse pelo que estava ensinando, usando a pergunta do aluno para dar uma seqüência na sua aula. Ele não seguia exatamente aquilo que achava que devia ser dado. Se um aluno fazia uma pergunta e se mais uma pergunta surgia 


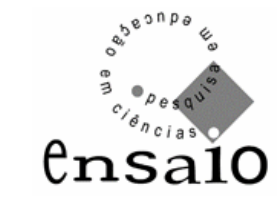

Vol. 11 no 1 junho 2009

naquele mesmo assunto, ele começava a seguir esse assunto. Ele não tentava dar o conteúdo que tinha pronto.

A fim de verificar se tais manifestações eram recorrentes, aplicamos um questionário a 78 licenciandos dos dois últimos semestres do referido curso, contendo duas questões abertas, para que indicassem qual/quais formador (es) das disciplinas de conteúdos específicos de Biologia mais contribui/contribuíram e/ou tem/têm contribuído para as suas futuras ações docentes e o porquê de tais indicações. A escolha desse formador se justificou por ter sido indicado pela grande maioria dos licenciandos (71\%). Além disso, a diferença percentual de sua indicação para o segundo escolhido, (37\%), reiterou o interesse de investigar sua prática pedagógica.

Para a construção e análise dos dados, adotamos a análise microgenética, fundamentada em uma abordagem histórico-cultural do desenvolvimento humano e em uma perspectiva enunciativa que prioriza a análise de processos. A análise microgenética pode ser caracterizada como uma forma de conhecer que é orientada para minúcias e ocorrências residuais, como indícios, pistas, signos de aspectos relevantes de um processo em curso; que elege episódios típicos e atípicos, os quais permitem interpretar o fenômeno de interesse; que é centrada na intersubjetividade e no funcionamento enunciativo-discursivo dos sujeitos; e que se guia por uma visão indicial e interpretativo-conjetural. Em síntese, uma "perspectiva de investigação da constituição de sujeito no âmbito dos processos intersubjetivos e das práticas sociais” (GÓES, 2000, p. 21).

Com base nessa abordagem, procuramos evidenciar no discurso pedagógico do formador como ele promove a elaboração de conhecimentos científicos em seus alunos. Para dar visibilidade a esse processo buscamos pistas, indícios nos seus enunciados, em suas falas e entonações com os alunos. Desse modo, para a análise do discurso do formador registramos suas interações verbais no contexto imediato de sua ocorrência, isto é, na sala de aula.

Com a permissão do formador, foram observadas e registradas em caderno de campo e em áudio cinco de suas aulas teóricas e práticas, com duração de duas horas cada uma. Esse número de observações resultou da nossa percepção sobre a manutenção do estilo docente do professor em suas ações na sala de aula. 


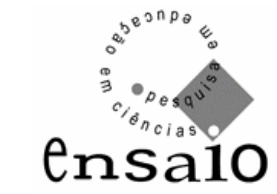

Vol. 11 no 1 junho 2009

As aulas foram referentes à disciplina de Fisiologia ministrada para uma classe de 65 alunos do $5^{\circ}$ semestre do referido curso. Os registros considerados para a investigação aqui proposta foram retirados de três aulas, nas quais foram abordados os seguintes temas: estresse, sistema sensorial e colesterol. Nas transcrições dessas aulas, e por meio da análise microgenética, foram recortados episódios que evidenciam aspectos do discurso do formador relativo ao como ele abordou a elaboração de conceitos em suas aulas. Esses aspectos incluem trechos das aulas em que há enunciações, falas e entonações do professor que indicam elaborações conceituais de um conhecimento específico em biologia/fisologia, assim como questões colocadas para o desenvolvimento de um conceito, perguntas e gestos dos alunos que apontam para interações entre o professor e os alunos. A partir disso organizamos os episódios apresentados nos resultados e discussões da seguinte maneira:

Episódio 1 - O discurso do formador na relação de ensino.

Episódio 2 - O jogo dialógico na elaboração conceitual.

Episódio 3 - Interações dinâmicas professor-aluno na elaboração conceitual

\section{RESULTADOS E DISCUSSÕES}

\subsection{Os cenários e aspectos gerais das aulas do formador}

Naquele contexto universitário, a grande maioria dos sessenta e cinco alunos da classe do quinto semestre eram trabalhadores, com idade média de vinte e dois anos. Muitos deles chegavam às aulas poucos minutos antes de seu início. Como era comum, em todas as aulas observadas, nesse momento o professor já estava rodeado por alguns alunos que haviam chegado mais cedo, conversando sobre assuntos variados ou esclarecendo dúvidas sobre os conteúdos de sua disciplina ou das de outros professores do curso.

As aulas de Fisiologia eram quatro semanais, distribuídas entre teóricas e práticas. Estas, na verdade, eram teóricas-práticas. As aulas teóricas, propriamente ditas, ocorriam na sala destinada àquela turma e estava sempre repleta, que nos parecia não faltar nenhum dos alunos. Esta sala era bastante espaçosa, com capacidade aproximada para oitenta alunos. Nela havia uma grande lousa e ventiladores de teto. 


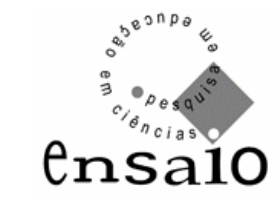

Vol. 11 no 1 junho 2009

As carteiras, antes do início da aula, eram organizadas em fileiras, mas logo eram mudadas de posição assim que os alunos as ocupavam. Alguns deles juntavam suas carteiras em duplas, outros as afastavam procurando um lugar com melhor visibilidade da lousa, outros ainda as mantinham do jeito que haviam encontrado.

Já as aulas práticas aconteciam no laboratório, próprio para as atividades prático-experimentais da disciplina de Fisiologia. Nessas aulas, a classe era dividida em duas turmas de trinta e dois e trinta e três alunos respectivamente, em horários diferentes. O laboratório, com capacidade para quarenta alunos, dispunha, também, de uma grande lousa, ventiladores de teto, quatro grandes bancadas com torneiras e cubas, e, ainda, vários armários nos quais eram guardados materiais e substâncias químicas. Os alunos se sentavam em grupos de quatro ou cinco em volta das bancadas.

No início de cada aula, tanto nas teóricas quanto nas práticas, o professor escrevia na lousa o tema central a ser tratado. Entregava a cada um dos alunos um texto auxiliar, geralmente sobre resultados de pesquisas referentes ao tema e/ou um resumo da aula. Depois disso, dirigia-se aos alunos, atraindo suas atenções para aula. Explicitava, então, o que seria abordado na aula, como pretendia desenvolvê-la e quais eram os objetivos da mesma.

Para a explanação dos temas e dos conceitos a eles relacionados, o professor utilizou, basicamente, a exposição oral, com uso de esquemas e desenhos na lousa e de transparências para reforçar/embasar suas explicações. No caso das aulas práticas, tais recursos foram, também, utilizados para o desenvolvimento dos conteúdos teóricos. Nesse desenvolvimento o professor procurava articular os conceitos centrais com outros conceitos a eles relacionados e com situações do cotidiano dos alunos. Especialmente, a utilização dessas situações, parecia-nos entusiasmar os alunos, que se mantinham silenciosos, mas numa atitude participante e atenta às explicações do professor. Esse comportamento dos alunos parecia-nos, também, ser reforçado pela própria postura do professor que, desde que iniciava a aula até o seu final, era de evidente entusiasmo e bom humor. Tal postura era marcada com muitos gestos, na entonação que usava para chamar atenção dos alunos para algo que queria destacar. Era marcada, também, pela forma como em muitos momentos ele interpelava os alunos, trazendo em sua fala a dúvida deles. 


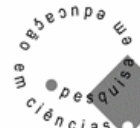 \\ ensa10}

Vol. 11 no 1 junho 2009

No final da aula o professor retomava de forma sintética os conceitos trabalhados durante a mesma. Terminada a aula, muitos alunos se reuniam ao seu redor para esclarecimento de dúvidas ou para discutir outros assuntos.

É nesses cenários que ocorreram os episódios das aulas analisadas.

\subsection{O discurso pedagógico na elaboração de conhecimentos}

A partir dos enunciados do formador nos episódios que apresentamos e analisamos a seguir, procuramos focalizar no seu discurso pedagógico como ele promove a elaboração conceitual em suas aulas.

\subsubsection{Episódio 1 - O discurso do formador na relação de ensino}

Este episódio se refere a uma aula prática, cujo tema abordado é Estresse. Nesta aula, o professor está no laboratório trabalhando com uma parte da turma, isto é, com trinta e dois alunos. Ele começa a aula escrevendo na lousa o tema ser abordado durante a mesma. Depois disso, dirige-se aos alunos dizendo:

Vou fazer uma aula diferente hoje, para você poder entender, para deixar bem claro o que eu quero trazer para você! Eu avalio stress por outra linha, eu não avalio direto pelo hormônio.(...) Mas, como é que eu vou gerar um stress para você poder entender e avaliar? Vou fazer uma avaliação, primeiro teórica para você de stress. Como é que nós vamos fazer um stress para poder avaliar e mostrar para esse pessoal? Então, a partir de agora, nosso amigo rato vai para o congelador! Ou seja, com 20 minutos de congelador, vou ensinar como é que eu avalio stress no bicho! Para que serve isso? Para a gente entender stress, ver coisas sobre o stress, mecanismos adaptativos. É o que nós vamos fazer! Você vai explicar o stress! Tem um texto que eu deixei que se chama "O estresse e suas implicações fisiológicas" e que acho que vale a pena ler. Vamos conversar um pouquinho de stress, porque eu queria deixar primeiro claro o que é o stress, para depois a gente reavaliar quais são esses mecanismos do stress. Primeira coisa que nós vamos entender, o indivíduo está acostumado a dizer assim: nossa!! Estou estressado!! Nossa, eu não agüento mais!! Na nossa concepção de fisiologia o stress vai ser a sua resposta, a resposta do seu organismo frente a uma condição indutora. Ou seja, vai existir uma condição quer seja física, quer seja psíquica, ou mista. E essas reações do indivíduo vão culminar com uma reação do seu organismo, uma resposta orgânica ou comportamental e isso vai ser o que nós vamos entender como stress. 


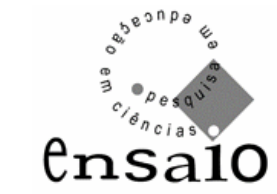

Vol. 11 no 1 junho 2009

A análise deste episódio evidencia alguns aspectos importantes do discurso pedagógico para a elaboração de conhecimentos na sala de aula. Um deles está relacionado à própria aula, cuja realização se faz predominantemente pela fala e tem especificidades que a configuram como um gênero discursivo. A fala professoral é uma "fala pública”, investida de autoridade, de saber legitimado na medida em que se dirige a um grupo bem definido - o dos alunos - que ocupa um lugar social hierarquicamente submetido ao do professor. Essa posição hierárquica dá à fala professoral a possibilidade de que seja levada em conta pelos interlocutores, isto é, pelos alunos (FONTANA, 2001, p. 34).

Assim, o primeiro aspecto é explicitado na medida em que, considerando a posição dos sujeitos na dinâmica interativa, o formador define o seu lugar social na relação assimétrica do processo de ensino-aprendizagem. Isso é indiciado quando ele utiliza, especialmente, a palavra eu, e, também, quando marca de modo deliberado uma forma de elaboração do conhecimento biológico/fisiológico, conforme suas falas contidas nesse episódio: vou ensinar como é que eu avalio stress.. Para que serve isso? Para a gente entender stress, ver as coisas sobre o stress, mecanismos adaptativos. É o que nós vamos fazer! Você vai explicar o stress! Na nossa concepção de fisiologia o stress vai ser a sua resposta, a resposta do seu organismo frente a uma condição indutora. Ou seja, vai existir uma condição quer seja física, quer seja psíquica, ou mista. E essas reações do indivíduo vão culminar com uma reação do seu organismo, uma resposta orgânica ou comportamental e isso vai ser o que nós vamos entender como stress.

Nesse sentido, podemos dizer que o formador faz uso de sua posição hierárquica na relação de ensino, com predominância do seu discurso nas aulas. Tal fato nos remete a um segundo aspecto importante para a compreensão do discurso pedagógico do formador no contexto de um curso universitário visando a elaboração de conceitos científicos: sua concepção sobre aluno e sobre o processo de ensinoaprendizagem. Esse aspecto é apresentado e discutido no episódio a seguir

\subsubsection{Episódio 2 - O jogo dialógico na elaboração conceitual}




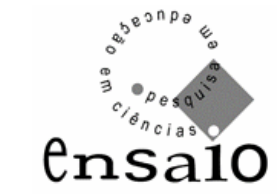

Vol. 11 no 1 junho 2009

Este episódio corresponde a uma aula teórica, na qual o tema abordado é Sistema Sensorial. Nesta aula, o professor está trabalhando com toda a turma, isto é, com os sessenta e cinco alunos. Do mesmo modo como iniciou a aula sobre estresse, ele escreve na lousa o tema a ser abordado, dizendo aos alunos:

O assunto de hoje: a representação sensorial que tem no organismo e as áreas cerebrais, mecanismos de ativação e alguns mecanismos que tem para entrada de sinal. Vamos pensar da seguinte maneira, qualquer informação sensitiva, sensorial vai sair de uma região periférica e vai caminhar em direção a uma área cerebral. Primeira coisa que você tem que entender: toda freqüência de sensações não existe na periferia! Ah, professor, impossível! Eu passo a mão aqui e sinto que é liso. Significa liso porque eu tenho um receptor que reconhece o sinal, transmite esse sinal, que passa pela medula e vai até uma região cerebral, onde a informação é processada para que seja tomada uma decisão e o sinal volte até a periferia. Todo sinal de entrada depende de uma célula específica para reconhecer um estímulo! Nas próximas aulas nos vamos falar um pouquinho sobre dor e eu vou usar algumas vias de dor para você entender. As informações que migram da periferia para o sistema nervoso central migram através do receptor. O receptor reconhece os estímulos, transmite-os para uma área cerebral. Ah, professor, não entendi! Quero dizer o seguinte, por exemplo, uma célula do campo visual, uma célula da retina, na hora que a luz bate nela há um potencial de ação, que vai lá na área cerebral. Nessa área há uma seqüência de potenciais de ação que vão montando a informação. Ah, professor, forma a informação visual? Vai para uma área cerebral, que é o córtex visual. E uma informação auditiva? Saiu da região do pavilhão auditivo, chegou a mensagem e mandou o fluxo lá para as áreas auditivas do cérebro! Primeira coisa que a gente tem que entender: se existem modalidades diferentes de sensação como calor, frio, pressão, tato, vibração, luz, dor, seja o que for, eu preciso organizar na pele uma seqüência de receptores diferenciados, de forma que transmitam a informação para o sistema nervoso central. Se você está mexendo com receptores de calor ou frio, você passou a mão, ele está dizendo frio ou calor. Se eu queimar esse receptor, ele não responde, o estímulo é específico! Existe um estímulo para cada tipo de receptor e ele migra para uma área cerebral, onde vai ser codificado. É isso que nós vamos ver! Vamos ver aí, diz para mim uma sensação, fala qualquer uma!

\section{Aluno - Dor!}

Professor - Dor! Imagina comigo, onde estão alguns dos receptores de dor? O receptor de dor é o mais bonito que tem, depois nós vamos falar dele. Mas, o receptor de dor não se dá ao luxo de ter muita camada para conseguir ativar, despolarizar e gerar o sinal. Normalmente receptores de dor são receptores cuja ativação é mais simples, mais rápida e são muito influenciados por oxigenação, por fluxo sanguíneo local! Por exemplo, o receptor de dor vai estar localizado numa região mais profunda da pele... 


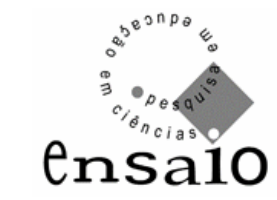

Vol. 11 no 1 junho 2009

Conforme dito anteriormente, para a explanação dos temas em suas aulas, o formador utilizou, basicamente, a exposição oral, com uso de esquemas e desenhos na lousa e de transparências para reforçar/embasar suas explicações. Nas aulas, conforme observamos, os alunos se mantiveram silenciosos, mas numa atitude participante e atenta às explicações do formador, o qual, em muitos momentos, os interpelava, incorporando em sua fala possíveis questões/dúvidas/falas deles. Por exemplo, quando o formador diz nesse episódio: Primeira coisa que você tem que entender: toda freqüência de sensações não existe na periferia! Ah, impossível! Eu passo a mão aqui e sinto que é liso. Significa liso porque eu tenho um receptor que reconhece o sinal. Ah, não entendi! Quero dizer o seguinte, por exemplo, uma célula do campo visual, uma célula da retina, na hora que a luz bate faz um potencial de ação, que vai lá na área cerebral. Nessa área junta uma seqüência de potenciais de ação e as seqüencias dos potenciais vão montando a informação. Ah, forma a informação visual? Vai para uma área cerebral, que é o córtex visual. E uma informação auditiva? Saiu da região do pavilhão auditivo, chegou a mensagem e mandou o fluxo lá para as áreas auditivas do cérebro!.

Apesar do gênero discursivo que caracteriza a aula, esta, como uma prática social, é um processo intersubjetivo e, assim, o seu desenvolvimento é afetado pelo auditório social ou pelos interlocutores. Isso porque o outro, a quem a aula se dirige, o aluno, "não é um ser mudo, privado da palavra. Mas, ao contrário, é um ser cheio de palavras interiores. Toda a sua atividade mental (...) é mediatizada para ele pelo discurso interior e é por aí que se opera a junção com o discurso apreendido do exterior. A palavra vai à palavra” (BAKHTIN, 1997, p. 147).

Nesse sentido, no episódio acima, ao incorporar em sua fala as possíveis falas/dúvidas/questões dos alunos, três interpretações para o discurso do formador podem ser feitas. Uma delas é a de ele não querer levar em consideração outras possíveis falas/dúvidas/questões dos alunos, uma vez que eles estão ali em sua presença e poderiam dizê-las por si mesmos, já que, de acordo com Bakhtin (1997, p. 147), “a apreensão ou a compreensão do discurso do outro é um processo dialógico de confrontação entre as palavras "alheias” e as palavras elaboradas pelo sujeito”.

Assim, no que diz respeito aos processos de linguagem presentes nesse discurso, parece-nos que está implicada uma idéia de que a palavra do formador deve 


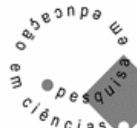 \\ ensa10}

Vol. 11 no 1 junho 2009

ser reiterada, parcial ou totalmente; sua meta, então, poderia ser a de que os alunos memorizassem suas palavras, situando-o em uma concepção tradicional do processo ensino-aprendizagem, típica do modelo transmissão-recepção (GOÉS, 1997).

No entanto, o desenvolvimento das aulas evidencia que o formador é afetado pelos alunos, pois parece que tem sempre em mente suas presenças, orientando o seu discurso para eles. Isso se manifesta quando ele inclui possíveis questões/dúvidas/falas dos alunos em suas próprias palavras. Nesta linha de interpretação, Smolka (2003, p. 42) aponta que:

[a] orientação para o outro no movimento de apreensão da palavra alheia delineia uma "terceira pessoa" (um "ele" generalizado), marcada pela ambiência cultural de uma época e que se configura como o auditório /horizonte social no qual se constitui e onde está imersa a consciência individual (...). Nesse contexto, o "outro" assume formas e configurações diversificadas: internalizado, generalizado, idealizado, desdobrado, o "outro" é um lugar de tensão que delineia os contornos da singularidade na dinâmica social, coletiva.

Assim, uma segunda interpretação do discurso do formador nesse episódio, é a de que os seus dizeres indiciam que ele concebe/entende seus alunos como sujeitos responsivos, que têm conhecimentos e que estão questionando e compreendendo suas explicações. Nesse caso, a própria atitude dos alunos durante as aulas, como observamos, silenciosa e atenta às explicações, a qual pode ser caracterizada como uma atitude responsiva, propicia tal entendimento ao formador. Conforme Bakhtin (2000, p. 291),

A compreensão responsiva nada mais é senão a fase inicial e preparatória para uma resposta (seja qual for a forma de sua realização). O locutor postula esta compreensão responsiva ativa: o que ele espera, não é uma compreensão passiva que, por assim dizer, apenas duplicaria seu pensamento no espírito do outro, o que espera é uma resposta, uma concordância, uma adesão, uma objeção, uma execução, etc. A variedade dos gêneros do discurso pressupõe a variedade dos escopos intencionais daquele que fala ou escreve.(...). O próprio locutor como tal é, em certo grau respondente, pois não é o primeiro locutor, que rompe pela primeira vez o eterno silêncio de um mundo mudo, e pressupõe não só a existência do sistema da língua que utiliza, mas também a existência dos enunciados anteriores - emanantes dele mesmo ou do outro - aos quais seu próprio enunciado está vinculado por algum tipo de relação (fundamenta-se neles, polemiza com eles), pura e simplesmente ele 


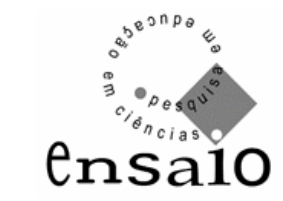

Vol. 11 no 1 junho 2009

já os supõe conhecidos do ouvinte. Cada enunciado é um elo da cadeia muito complexa de outros enunciados.

Desse modo, o discurso acima destacado mostra que o formador procura articular o que acredita que os alunos já sabem e as suas possíveis dúvidas com o que está ensinando. Mostra também, que seu discurso está povoado das vozes dos alunos, de outros alunos que já teve, dos livros, dos conhecimentos que detém, que o ajudam a elaborar os seus dizeres para organizar as idéias dos alunos e ensiná-los, pois como diz Bakhtin (2000, p. 316), “o enunciado está repleto de ecos e lembranças de outros enunciados, aos quais está vinculado no interior de uma esfera comum da comunicação verbal”. Então, completa o autor, “o enunciado deve ser considerado acima de tudo como uma resposta a enunciados anteriores dentro de uma dada esfera, refuta-os, confirma-os, complementa-os, baseia-se neles, supõe-nos conhecido e, de um modo ou de outro, conta com eles".

Nesses termos, o discurso pedagógico do formador nos remete ao que Góes (1997, p. 27) aponta: “que o jogo dialógico entre sujeitos não tende a uma só direção; ao contrário, envolve circunscrição, ampliação, dispersão e estabilização de sentidos. Um determinado conhecimento (pretendido, na intencionalidade do outro; ou previsto, na perspectiva de um observador) pode ou não ser construído pelo indivíduo”.

Desse modo, uma terceira interpretação a ser considerada sobre o discurso pedagógico do formador poderia envolver uma possível atividade compartilhada com seus alunos, já que em sua fala ele traz vozes de suas experiências, nas quais as deles podem estar também incorporadas. Assim, se por um lado, o formador usualmente não abre espaço para que os alunos exponham por eles próprios suas dúvidas, seus conhecimentos, suas concepções, por outro, ainda que não os perguntando diretamente, ele indicia agir como se contemplasse ou incorporasse as suas falas ao falar por eles. Mas, a atividade compartilhada entre professor e alunos aparece quando ele abre, de fato, espaço para que estes falem ao pedir que dêem um exemplo de sensação e um aluno fala: Dor! E o professor acata dizendo: Dor!!! Imagina comigo, onde estão alguns dos receptores de dor? O receptor de dor é o mais bonito que tem, depois nós vamos falar dele, e prossegue explicando sobre essa sensação.

Esse episódio evidencia, além da atividade compartilhada, um tom valorativo à participação ou à fala do aluno, especialmente, quando ele enfatiza a palavra “dor”. 


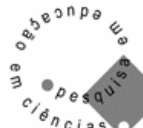 \\ ensa10}

Vol. 11 nำ junho 2009

Segundo Bakhtin (2000, p. 396), “o tom não é determinado pelo material do conteúdo do enunciado ou pela vivência do locutor, mas pela atitude do locutor para com a pessoa do interlocutor (atitude do locutor para com sua posição social, para com sua importância, etc.)”.

Nessa visão, tal valoração se acentua quando o formador diz: depois nós vamos falar dele, e acata a sugestão do aluno e antecipa um pouco do conteúdo que ele trataria em outros momentos, demonstrando que o seu planejamento de aula não é fixo e determinado, mas se modifica e se movimenta a partir das necessidades encontradas na sala de aula. Tal fato acontece, também, quando o professor está desenvolvendo o conteúdo sobre colesterol e os alunos intervêm, como apresentamos no próximo episódio.

\subsubsection{Episódio 3 - Interações dinâmicas professor-aluno na elaboração conceitual}

Este episódio é de uma aula prática, cujo tema abordado é Colesterol. Como na aula sobre estresse, o professor está no laboratório trabalhando com uma parte da turma. Ele começa a aula escrevendo na lousa o tema que vai abordar. Depois, dirigese aos alunos dizendo:

Eu queria conversar um pouquinho com você sobre o colesterol e algumas coisas que eu trouxe: uma foto na transparência que eu achei interessante para todo mundo conhecer. Então, antes de falar de colesterol, dá uma olhada nessa foto aqui! Olha, o problema todo para começar a nossa conversa. A história começa com as propriedades dos vasos, uma parede de vaso, que possui uma luz interna, aonde tem o fluxo de sangue. Por alguns hábitos alimentares ou por disfunção hepática, essa luz pode ter uma obstrução quase completa. Essas grandes placas de formação de gordura dentro da artéria me chamaram a atenção para a gente voltar a conversar sobre hábito alimentar. Vamos repassar desde o período da biofísica, quando dizia que a membrana tinha uma porção protéica, que tinha como função receptor, transportador, carreador. Passando pela estrutura da membrana, tinha cadeia de ácidos graxos com aquela dobra típica para evitar empacotamento. Associado a isso, no meio dos lipídios, tinha uma molécula de colesterol. Aquele colesterol que nós vimos na membrana, que dá flexibilidade, que mantém a impermeabilidade, o vazamento entre lipídios e membrana, aquele é o colesterol que tem um efeito benéfico para o organismo, diferente de outras moléculas de colesterol, que são essas que nós vamos ver, que podem ter um efeito benéfico, como podem não ter esse efeito. Então, eu queria começar por aqui, principalmente porque é dessas moléculas de colesterol que nós vamos falar. O HDL que é o bom e o LDL que é o ruim. É o que nós vamos ver! $\mathrm{O}$ que a gente tem que entender é que quem se alimenta muito com dieta rica em gordura, principalmente gordura saturada, tem maior probabilidade do colesterol plasmático LDL circulante ser maior e dele se ligar 


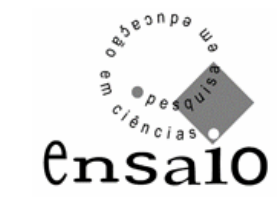

Vol. 11 no 1 junho 2009

à parede de uma artéria. Se ele se ligar na parede da artéria vai começar a gerar nódulos. Esses nódulos vão fazer com que ocorra o comprometimento do fluxo sangüíneo. Com esse comprometimento vai desencadear uma resposta que não é nada mais do que um acúmulo de placas de gordura! Quando essa estrutura começa se infiltrar na parede da artéria, começa a fazer sistemas de trombos, aonde uma plaqueta vem e liga na outra através de uma bolinha que se chama tromboxan. Aí, começa a fazer um tampão plaquetário.....

Aluno - É placa de ateroma?

Professor - É! Placa de ateroma! Que cola uma, que cola outra, pode calcificar e vai fechando a luz do vaso. Esse fechamento vai criando cada vez mais uma obstrução do centro do vaso e reduzindo a passagem do sangue dentro do vaso. Ou, seja, desencadeia uma resposta a partir da parede do vaso, que começa a gerar um estreitamento do local onde tem um fluxo sangüíneo.

Aluna - Para que servem a arteriografia e o cateterismo?

Professor - A arteriografia é um exame para avaliar o quanto de fluxo sanguíneo passa naquela artéria. Arteriografia! E o cateterismo é um procedimento que você faz na tentativa de desobstruir as vias de passagem pela artéria. Vamos caminhar mais um pouquinho! Nós vamos pegar duas frações que interessam muito para a gente! Uma fração que é o LDL, que é uma proteína de baixa densidade. Essa LDL transporta o colesterol no organismo. Vamos entender o seguinte, o LDL leva o colesterol e traz o colesterol da parede da artéria. E o HDL, que é de alta densidade, remove esse colesterol, não deixando que ele fique colado em grande quantidade na parede da artéria...

O diálogo entre formador e seus alunos apresentado nesse episódio evidencia que ele responde a eles, mesmo quando suas perguntas “desviam” do tema central da aula, configurando uma perspectiva dialógica em suas aulas. Tal perspectiva parece estar presente, também, nos textos que ele traz aos alunos, no intuito de promover a compreensão deles sobre o conteúdo tratado na aula, conforme constante no primeiro episódio da aula sobre estresse : Tem dois textos que eu deixei e que tratam da grande interpretação fisiológica do estresse e que acho que vale a pena de ler.

Assim, ao desenvolver suas ações pedagógicas, abrindo espaço à fala/dúvidas/questões dos alunos, mesmo que muitas vezes em sua própria fala, bem como o movimento dialógico na interação de diferentes vozes como a das experiências, dos textos científicos postos em sala de aula, o discurso do formador remete ao que diz Machado (1999) com base no pensamento de Bakhtin: que nas interações em sala de aula encontram-se e confrontam-se vozes do livro didático, de textos científicos, do professor, de experiências e do conhecimento cotidiano, tudo isso fazendo parte do processo de elaboração de conhecimentos. 


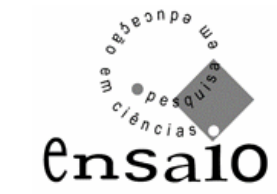

Vol. 11 no 1 junho 2009

\section{CONSIDERAÇÕES FINAIS}

Os resultados da investigação aqui apresentados evidenciam que na relação de ensino, o processo de elaboração de conhecimentos não consiste em um processo "predominantemente harmonioso; e de que o outro teria um papel homogêneo e, em essência, “pedagógico” (GÓES, 1997, p. 23). Mesmo na sala de aula, o conhecimento parece acontecer tanto em acordo quanto em desacordo com as características uniformes, esperadas ou idealizadas das relações entre sujeitos”. Nesse sentido, os dados da investigação nos mostram que o discurso pedagógico do formador apresenta vários efeitos na sala de aula. Um deles diz respeito ao fato de que ele conduz os alunos a certas formas de conhecimento valorizados e legitimados socialmente de acordo com as práticas institucionais de formação, aqui no caso, no campo Licenciatura em Ciências Biológicas. Um outro aspecto refere-se ao fato de que ele direciona e silencia formas de conhecimentos, dúvidas/questões que os alunos têm ou possam ter, evidenciando uma interpretação do processo ensino-aprendizagem em termos de transmissão-recepção. Nesse sentido, podemos destacar, também, que apesar de haver um silenciamento das concepções/dúvidas/questões dos alunos, de alguma forma elas são contempladas, mesmo que pela voz do formador, que procura evidenciá-las, explicitando seus limites e verbalizando o processo de elaboração conceitual. Outros aspectos estão relacionados à perspectiva dialógica posta em sala de aula, ao abrir espaço para os alunos se expressarem, ao trazer textos com temas atuais, situações da vida cotidiana que expressam outras vozes do conhecimento científico e do conhecimento cotidiano, as quais se articulam e confrontam-se no processo de elaboração conceitual.

Tais resultados nos levam a considerar com Góes (1997) que no âmbito do processo de elaboração de conhecimentos em sala de aula, especialmente no contexto universitário referendado neste trabalho, não temos como atenuar a complexidade das interações entre os sujeitos e nem esquecer o caráter, muitas vezes, contraditório dessas interações. Nesta contradição, parece prevalecer o planejamento do professor, aquilo que precisa ser cumprido, ser ensinado e aí o predomínio do discurso docente é arma fundamental. Mesmo querendo levar em conta idéias dos alunos, parece 


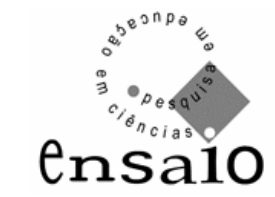

Vol. 11 no 1 junho 2009

importante para o nosso professor universitário construir e utilizar mecanismos discursivos que assegurem o que ele considera ser a condição fundamental do processo escolar, qual seja, a de transmitir conhecimentos. No entanto, como articular os discursos do mestre e dos alunos? Se esse contexto revela facetas significativas da complexidade docente e escolar, então, concordamos com Góes (1997) que é nesse contexto que o processo de elaboração de conhecimentos precisa ser analisado para melhor compreender a problemática enfocada na introdução deste trabalho. Portanto, a importância que podemos perceber nos dados apresentados se situa no fato de adentrarmos a sala de aula de um professor universitário de disciplina científica e procurarmos desvelar aspectos de seu discurso pedagógico que permitem o acréscimo de mais um olhar para a complexidade da formação docente.

\section{REFERÊNCIAS BIBLIOGRÁFICAS}

BAKHTIN, M. Marxismo e filosofia da linguagem. São Paulo: HUCITEC, 1997.

BAKHTIN, M. Estética da criação verbal. São Paulo: Martins Fontes, 2000.

CARVALHO, A. M. P. e GIL-PÉREZ, D. Formação de professores de ciências: tendências e inovações. São Paulo: Cortez, 1993.

FONTANA, R. A. C. Mediação pedagógica na sala de aula. Campinas: Autores Associados, 1996.

FONTANA, R. A. C. Sobre a aula: uma leitura pelo avesso. Presença Pedagógica. v. 7, n 39, pp. 31-37, 2001.

FONTANA, R. A. C. A elaboração conceitual: a dinâmica das interlocuções na sala de aula. In: SMOLKA, A. L. B; GÓES, M. C. R. (orgs.). A linguagem e o outro no espaço escolar: Vygotsky e a construção do conhecimento. Campinas: Papirus 2003.

GÓES, M. C. R. As relações intersubjetivas na construção de conhecimentos. In: GÓES, M. C. R. e SMOLKA, A. L. B. (orgs.). A significação nos espaços educacionais: Interação social e subjetivação. Campinas: Papirus, 1997.

GÓES, M. C. R. A abordagem microgenética na matriz histórico-cultural: Uma perspectiva para o estudo da constituição da subjetividade. Cadernos CEDES. 1.ed. Campinas, $n^{\circ}$ 50, p. 21-29, 2000.

MACHADO, A. H. Aula de química: discurso e conhecimento. Ijuí: UNIJUÍ, 1999. 


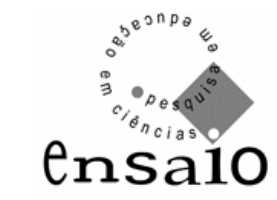

Vol. 11 no 1 junho 2009

MALDANER, O. A. A formação inicial e continuada de professores de química. Ijuí: UNIJUÍ, 2000.

MARCELO, C. G. Formação de Professores - para uma mudança educativa. Barcelona: Porto Editora, 1999.

SCHNETZLER, R. P. O professor de ciências: problemas e tendências de sua formação. In: SCHNETZLER, R. P. e ARAGÃO, R. M. R. (orgs.). Ensino de Ciências: fundamentos e abordagens. Piracicaba: CAPES/UNIMEP, 2000.

SMOLKA, A. L. B. A Esboço de uma perspectiva teórico-metodológica no estudo de processos de construção de conhecimento. In: GÓES, M. C. R. e SMOLKA, A. L. B. (orgs.). A significação nos espaços educacionais: Interação social e subjetivação. Campinas: Papirus, 1997.

SMOLKA, A. L. B. O (im)próprio e o (im)pertinente na apropriação das práticas sociais. Cadernos CEDES, Campinas, nº 50, p. 26-40, 2000.

VYGOTSKY, L. S. Pensamento e Linguagem. 2.ed. São Paulo: Martins fontes, 2000a.

VYGOSKY, L. S. A formação social da mente. São Paulo: Martins Fontes, 2000b.

Data de recebimento: 20/12/07

Data de aprovação: 12/09/08

Data de versão final: 24/10/08 